\title{
Central nervous system lymphoma: magnetic resonance imaging features at presentation
}

\author{
Linfoma do sistema nervoso central: características da imagem de ressonância \\ magnética à apresentação \\ Ricardo Schwingel', Fabiano Reis², Veronica A. Zanardi², Luciano S. Queiroz ${ }^{3}$, Marcondes C. França Jr. ${ }^{4}$
}

\begin{abstract}
Objective: This paper aimed at studying presentations of the central nervous system (CNS) lymphoma using structural images obtained by magnetic resonance imaging (MRI). Methods: The MRI features at presentation of 15 patients diagnosed with CNS lymphoma in a university hospital, between January 1999 and March 2011, were analyzed by frequency and cross tabulation. Results: All patients had supratentorial lesions; and four had infra- and supratentorial lesions. The signal intensity on T1 and T2 weighted images was predominantly hypo- or isointense. In the T2 weighted images, single lesions were associated with a hypointense signal component. Six patients presented necrosis, all of them showed perilesional abnormal white matter, nine had meningeal involvement, and five had subependymal spread. Subependymal spread and meningeal involvement tended to occur in younger patients. Conclusion: Presentations of lymphoma are very pleomorphic, but some of them should point to this diagnostic possibility.
\end{abstract}

Key words: lymphoma, central nervous system, magnetic resonance imaging.

\section{RESUMO}

Objetivo: Este trabalho teve como objetivo estudar as apresentações do linfoma do sistema nervoso central (SNC) por meio de imagens estruturais, obtidas por ressonância magnética (RM). Métodos: Foram analisadas as características das imagens por RM, à apresentação, de 15 pacientes diagnosticados com linfoma do SNC em um hospital universitário, entre janeiro de 1999 e março de 2011, pela frequência e por tabulação cruzada. Resultados: Todos os pacientes apresentaram lesões supratentoriais; em quatro (27\%) havia lesões infra e supratentoriais. A intensidade do sinal em T1 e T2 foi predominantemente hipo ou isointensa. Lesões únicas foram associadas ao componente de sinal hipointenso nas imagens ponderadas em T2. Seis pacientes apresentaram necrose. Foram encontrados: alteração de sinal da substância branca perilesional em todos os pacientes, acometimento meníngeo em nove e disseminação subependimária em cinco. Disseminação subependimária e acometimento meníngeo tenderam a ocorrer nos pacientes mais jovens. Conclusão: As apresentações do linfoma no SNC são pleomórficas, mas algumas delas podem apontar para essa possibilidade diagnóstica.

Palavras-Chave: linfoma, sistema nervoso central, imagem por ressonância magnética.

Intracranial lymphoma may present essentially as primary central nervous system (CNS) B-cell non-Hodgkin lymphoma (B-cell PCNSL), metastatic CNS lymphoma, intravascular lymphomatosis, T-cell PCNSL, and intracranial Hodgkin's lymphoma ${ }^{1,2}$. The tumor has an infiltrative nature, and early diagnosis is important to guide proper treatment. Surgical removal has a limited role because it does not improve prognosis ${ }^{3,4}$.

Magnetic resonance imaging (MRI) may provide relevant diagnostic information for patients with suspected CNS lymphoma ${ }^{2}$. The radiological presentation may have a pattern of parenchymal, meningeal, or cranial nerve involvement ${ }^{2}$. Many inflammatory and neoplastic conditions may mimic these MRI patterns, so that radiologists should be aware of the diverse MRI features of CNS lymphoma ${ }^{5,6}$. Despite this, there are few studies specifically devoted to describe MRI abnormalities in this disease $\mathrm{e}^{2,4,5,7-11}$. Therefore, we presented a detailed description and analysis of MRI data of a large series of Brazilian patients with histological confirmation of CNS

School of Medical Sciences, State University of Campinas, Campinas, São Paulo SP, Brazil.

${ }^{1}$ Medical Student;

${ }^{2} \mathrm{MD}$, PhD, Professor, Department of Radiology;

${ }^{3} \mathrm{MD}$, PhD, Professor, Department of Pathology;

${ }^{4} \mathrm{MD}$, PhD, Professor, Department of Neurology.

Correspondence: Fabiano Reis; Faculdade de Ciências Médicas, Universidade Estadual de Campinas, Departamento de Radiologia; Rua Tessália Vieira de Camargo 126 / Caixa Postal:6111 / Cidade Universitaria Zeferino Vaz; 13083-887 Campinas SP - Brasil; E-mail: fabianoreis2@gmail.com

Support: FAPESP process no. 2010/01939-0.

Conflict of interest: There is no conflict of interest to declare.

Received 05 August 2011; Received in final form 04 November 2011; Accepted 11 November 2011 
lymphoma, in order to study the radiological characteristics of the disease at presentation.

\section{METHODS}

We analyzed the MRI findings at presentation of 15 immuno- and non-immunocompetent patients (4 men and 11 women), with a mean age of 42 years-old [19 to 77 years-old; standard deviation (SD): 17.9 years-old], diagnosed with primary or secondary CNS lymphoma. The images were performed at the State University of Campinas (UNICAMP) hospital between January, 1999 and March, 2011. The diagnosis was confirmed after surgical biopsy or tumor excision of all patients, according to clinical indication. The surgical specimens were processed for routine histopathology, and the classification of tumor type followed the World Health Organization (WHO) guidelines. The project was submitted to the Ethics Committee of our service, which approved the research protocol.

MRI scans were performed using a $2 \mathrm{~T}$ scanner (Elscint Prestige, Haifa, Israel), with T1 and T2 acquisitions in three orthogonal planes, including T1-weighted SE gadoliniumenhanced images. MRI acquisition parameters were: sagittal T1 spin echo, $6 \mathrm{~mm}$ thick; flip angle $=180^{\circ}$; repetition time $(\mathrm{TR})=430$ milliseconds; echo time $(\mathrm{TE})=12$ milliseconds; matrix 200 $\times 350$; field of view $(\mathrm{FOV})=25 \times 25 \mathrm{~cm}^{2}$; T2-weighted and "fast spin echo" (FSE), $3 \mathrm{~mm}$ thick; flip angle $=160^{\circ}$; $\mathrm{TR}=4,800$ milliseconds; $\mathrm{TE}=108$ milliseconds; matrix $256 \times 256$; FOV $=22 \times 22 \mathrm{~cm}^{2}$; axial T1-weighted spin echo (SE): TR=540 milliseconds; TE=28 milliseconds. T1-weighted SE gadolinium-enhanced images were obtained in the three orthogonal planes.

We analyzed the following variables: age, sex, HIV infection, uniqueness or multiplicity of the lesion, tumor location, signal on T1 and T2-weighted images, necrosis, contrast enhancement, perilesional white matter changes, meningeal involvement, subependymal spread, primary site of the lymphoma, and histological subtype.

For the images' evaluation, necrosis was defined as an area within a contrast-enhancing lesion that did not enhance on T1-weighted images and produced a hyperintense signal on T2-weighted images. Further, white matter changes were classified as mild, moderate or pronounced, depending on whether the hyperintense perilesional area on T2-weighted images was smaller, similar or larger than the enhanced lesion area on T1-weighted images after contrast injection, respectively.

For statistical analysis, findings were grouped into categories, according to the variability of results. The variables were then compared by means of cross tabulation and the application of Fisher's exact, Mann-Whitney's, and KruskalWallis' tests.

\section{RESULTS}

Tables 1 to 3 summarize the patients' data. Fourteen out of the 15 patients were seronegative for HIV. We found multiple parenchymatous lesions (intra-axial) on MRI scans in seven patients (47\%), as seen in Fig 1. Single lesions were identified in eight patients (53\%). Out of these eight patients with single lesions, six had intra-axial lesions, and two had extra-axial lesions.

Regarding the location of the lesions, supratentorial ones were found in all patients. We found 13 cases with intra-axial lesions; 9 had cortical or subcortical lobar lesions; and 10 had deep lesions involving the corpus callosum (Fig 2) or the centroencephalic region. There were four patients with concomitant infra- and supratentorial lesions: three had brainstem lesions, specifically involving the midbrain and one had a cerebellar lesion. There was no patient with spinal cord involvement, but we detected one immunocompetent patient with concomitant lesions in the hypothalamus and optic nerves.

Table 1. Patients and magnetic resonance imaging lesions data.

\begin{tabular}{|c|c|c|c|c|}
\hline Case & $\begin{array}{l}\text { Sex/ } \\
\text { Age }\end{array}$ & HIV & $\begin{array}{l}\text { Single or } \\
\text { multiple } \\
\text { lesions }\end{array}$ & Lesion sites \\
\hline 1 & $+9 / 32$ & pos & single & $\begin{array}{l}\text { Frontal, temporal, cortical and } \\
\text { subcortical }\end{array}$ \\
\hline 2 & $3 / 22$ & neg & multiple & $\begin{array}{c}\text { Deep and cortical, subcortical, } \\
\text { corpus callosum }\end{array}$ \\
\hline 3 & $3 / 22$ & neg & single & Frontal (extra-axial) \\
\hline 4 & q /77 & neg & multiple & $\begin{array}{l}\text { Thalamus, striatum, internal } \\
\text { capsule, with perivascular } \\
\text { spread, cortical, subcortical, } \\
\text { frontal, parietal, temporal, } \\
\text { midbrain }\end{array}$ \\
\hline 5 & $9 / 42$ & neg & single & Temporal fossa (extra-axial) \\
\hline 6 & $q / 57$ & neg & single & Frontal, subcortical, thalamus \\
\hline 7 & $q / 48$ & neg & multiple & $\begin{array}{l}\text { Frontal (intra-axial), } \\
\text { parietal (extra-axial) }\end{array}$ \\
\hline 8 & $+/ 32$ & neg & multiple & Frontal, corpus callosum \\
\hline 9 & $+/ 53$ & neg & single & $\begin{array}{l}\text { corpus callosum and } \\
\text { cingulate gyrus }\end{array}$ \\
\hline 10 & $+/ 51$ & neg & multiple & $\begin{array}{l}\text { Corpus callosum and } \\
\text { cerebellum }\end{array}$ \\
\hline 11 & $q / 19$ & neg & single & $\begin{array}{l}\text { Corpus callosum, thalamus, } \\
\text { midbrain and septum } \\
\text { pellucidum }\end{array}$ \\
\hline 12 & $3 / 52$ & neg & single & $\begin{array}{l}\text { Periventricular, deep (occipital, } \\
\text { temporal), corpus callosum }\end{array}$ \\
\hline 13 & $3 / 30$ & neg & multiple & $\begin{array}{l}\text { Midbrain, periventricular, basal } \\
\text { ganglia, corpus callosum, } \\
\text { striatum, internal capsule }\end{array}$ \\
\hline 14 & $+/ 23$ & neg & multiple & $\begin{array}{l}\text { Optic nerves, sellar and } \\
\text { suprasellar regions, temporal }\end{array}$ \\
\hline 15 & q/68 & neg & single & $\begin{array}{l}\text { Temporal, cortical and } \\
\text { subcortical }\end{array}$ \\
\hline
\end{tabular}

pos: positive; neg: negative. 


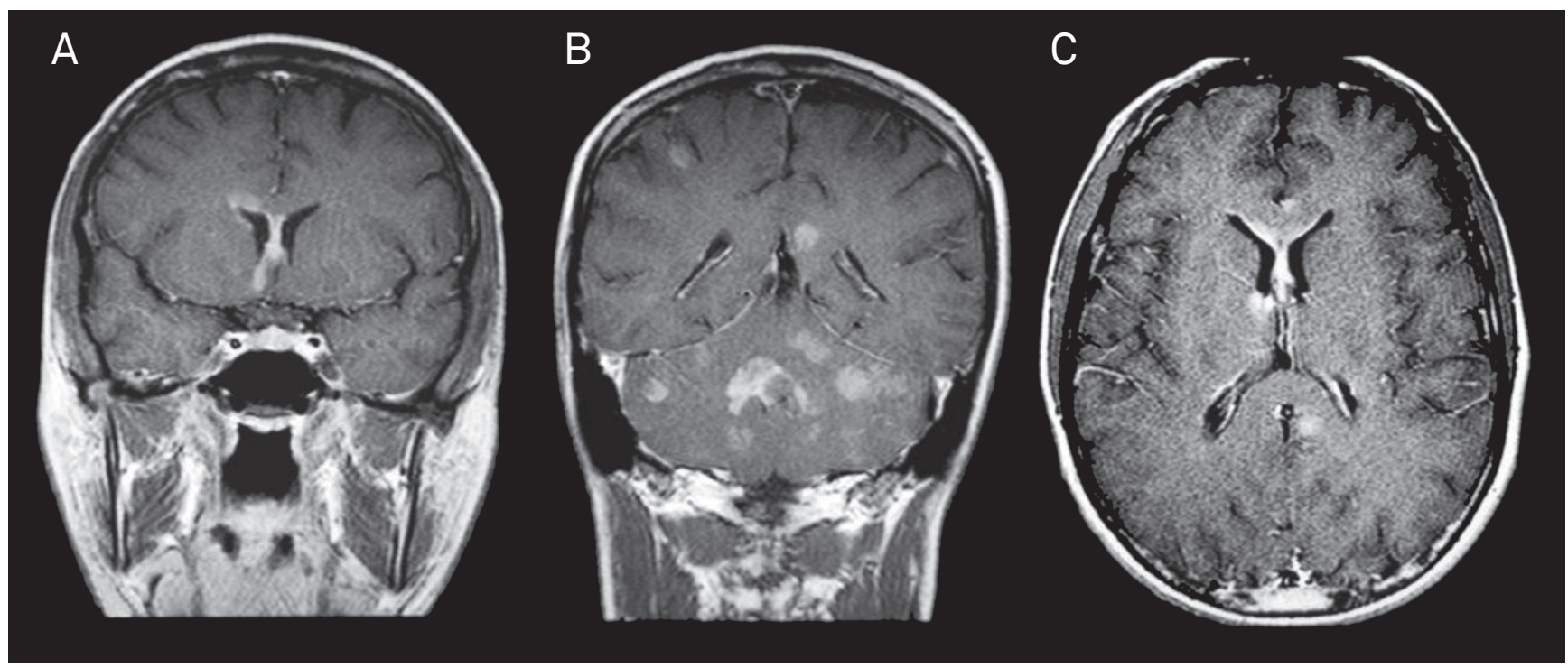

Fig 1. Case 2: Coronal T1 post-contrast (A and B) and axial T1 post-contrast (C) showing multiple and deep, cortical, and subcortical lesions that reach the genu of the corpus callosum. The second image (B) shows contrast enhancing nodules in the cerebellar parenchyma and leptomeningeal enhancement. There is also subependymal spread. The central nervous system involvement was secondary to non-Hodgkin lymphoma of B-cell phenotype.

On T1-weighted images, we observed four cases $(27 \%)$ with hypointense signal, six (40\%) with isointense signal, one (7\%) with hyperintense and four cases (27\%) with mixed ones. On T2-weighted images, there were seven cases (47\%) with hypointense signal, three (20\%) with isointense signal, one (7\%) with hyperintense signal, and four (27\%) with mixed signals. There was a significant difference $(\mathrm{p}<0.05)$ between the T2 weighted image signal of the group with single lesions and the group with multiple ones. In $62 \%$ of the cases with a single lesion, these presented with a hypointense signal component in the T2 weighted image ( $\downarrow$ or $\downarrow$ and =, Table 2 ), while in $42.9 \%$ of the cases, in which there were multiple lesions, it was possible to find the association of lesions with hypointense and hyperintense signals on the T2 weighted image ( $\downarrow$ and $\uparrow$, Table 2).

Necrosis was observed in six patients (40\%). Contrast enhancement was observed in 14 patients (93\%); in 6 cases, it was homogeneous. The perilesional white matter signal change was pronounced in four, moderate in five and mild in six cases. There was a significant association $(p<0.05)$ between the signal of the lesion in the T1 weighted image and the degree of perilesional white matter change. The group with lesions presenting a hyperintense signal component on the $\mathrm{T} 1$ weighted image (= and $\uparrow$ or $\uparrow$, Table 2$)$, and the area with perilesional signal changes tended to be more pronounced, while in the group with lesions presenting a hypointense signal component on the T1 weighted image ( $\downarrow$ or $\downarrow$ and $=$, Table 2), the area with abnormal perilesional signal tended to be smaller.

Meningeal involvement was identified in ten patients (59\%): leptomeningeal in four (27\%), dural in four (27\%), and one patient had both dural and leptomeningeal involvement. There was a trend of association $(\mathrm{p}=0.066)$ of age and

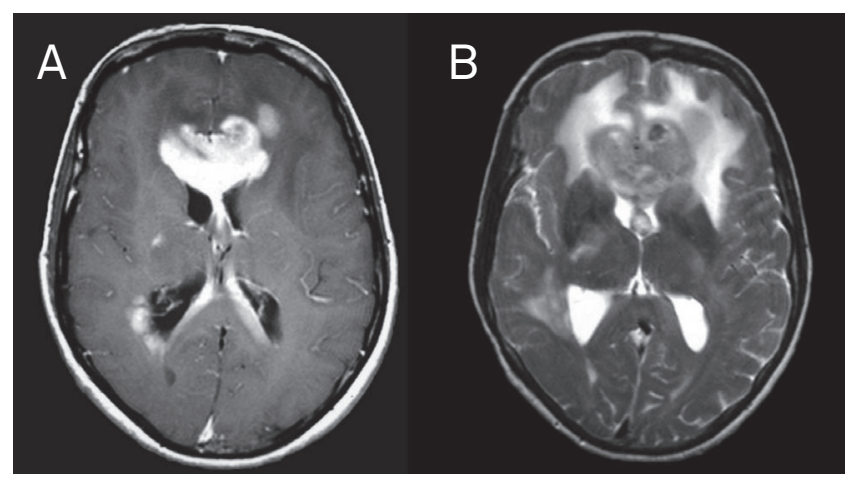

Fig 2. Case 10: Axial T1-weighted MRI after contrast (A) shows lesions in the genu and splenium of the corpus callosum. The contrast enhancement is intense and subependymal spread is observable. The T2 weighted image (B) shows a heterogeneous lesion with iso/hypointense signal. There is a hyperintense signal in the surrounding white matter. In this case, the central nervous system was primarily affected and the pathology showed a diffuse large B-cell non-Hodgkin lymphoma (centroblastic).

meningeal involvement. In the group of patients with meningeal involvement, the mean age was lower (35.1 years-old, $\mathrm{SD}=14.6$ years-old) than in the group of patients without meningeal involvement (52.0 years-old, $\mathrm{SD}=18.8$ years-old).

Subependymal dissemination was found in five patients $(33 \%)$. We found a significant association $(\mathrm{p}<0.05)$ of age and subependymal spread. The group of patients with subependymal spread had a lower mean age (27.4 years-old, SD=13.2 yearsold) than the one without subependymal spread (49.1 yearsold, $\mathrm{SD}=15.7$ years-old). There was no statistical significance $(p<0.05)$ in the analysis of cross tabulation of other variables.

Information on the primary site of lymphoma and pathology are shown in Table 3. 


\section{DISCUSSION}

Most of the analyzed patients were immunocompetent at diagnosis. Our finding of single lesions in $53 \%$ of patients is as expected according to the literature. This ratio ranged from $33 \%$, in a series analyzing mixed groups of immunocompetent and immunodeficient patients, to $81 \%$, in a series that analyzed only immunocompetent patients ${ }^{4,5,7-11}$.

Furthermore, our data are in line with works that show that the supratentorial region is usually more affected than the infratentorial region ${ }^{1,2,6,9,12}$. Midbrain and cerebellum were the affected sites in patients with infratentorial lesions in our paper, but they are two unusual sites affected by lymphoma in the $\mathrm{CNS}^{4,7,8}$.
The signal features in MRI conventional sequences depend on the tissue characteristics. More solid lesions with little or no necrosis appear as hypo- or isointense images on T2-weighted sequences, and with isointense signal on T1weighted images. These usually present strong enhancement after contrast injection ${ }^{11}$. The absence of necrosis in a bulky and infiltrative T2-hypointense lesion in the corpus callosum is not a frequent finding, but is rather specific and thus highly suggestive of lymphoma ${ }^{7}$. On the opposite, if a lesion has a large component of necrosis, which is usually described in immunocompromised patients, this more liquefied component tends to have a hypointense signal on T1-weighted images, a hyperintense signal on T2-weighted images, and a surrounding ring enhancement $t^{2,5,6,8,11,12}$.

Table 2. Magnetic resonance imaging lesions characteristics.

\begin{tabular}{|c|c|c|c|c|c|c|}
\hline Case & T1/T2 Signal & Necrosis & $\begin{array}{c}\text { Contrast } \\
\text { enhancement }\end{array}$ & $\begin{array}{l}\text { Perilesional white } \\
\text { matter signal change }\end{array}$ & $\begin{array}{l}\text { Meningeal } \\
\text { involvement }\end{array}$ & $\begin{array}{l}\text { Subependimal } \\
\text { dissemination }\end{array}$ \\
\hline 1 & $=$ and $\uparrow / \downarrow$ & Yes & Yes $($ heteroA) & Moderate & $\begin{array}{l}\text { Yes (dural) and } \\
\quad(\text { leptoc) }\end{array}$ & No \\
\hline 2 & $=/ \downarrow$ and $\uparrow$ & No & yes $\left(\right.$ homo $\left.{ }^{\mathrm{B}}\right)$ & Mild & Yes (lepto) & Yes \\
\hline 3 & $=$ and $\uparrow / \downarrow$ & No & yes (hetero) & Pronounced & Yes (dural) & Yes \\
\hline 4 & $\downarrow /=$ and $\uparrow$ & Yes & yes (hetero) & Mild & No & No \\
\hline 5 & $=/=$ & No & yes (homo) & Moderate & Yes (dural) & No \\
\hline 6 & $\uparrow / \downarrow$ & No & yes (hetero) & Pronounced & Yes (dural) & No \\
\hline 7 & $\begin{array}{l}\downarrow \text { and }=/ \\
\downarrow \text { and } \uparrow\end{array}$ & Yes & yes (hetero) & Pronounced & Yes (dural) & No \\
\hline 8 & $=/ \downarrow$ & Yes & yes (hetero) & Moderate & No & No \\
\hline 9 & $\downarrow$ and $=/ \downarrow$ & No & yes (homo) & Pronounced & No & No \\
\hline 10 & $=/ \downarrow$ and $\uparrow$ & Yes & yes (hetero) & Moderate & Yes (lepto) & Yes \\
\hline 11 & $\downarrow /=$ & No & yes (homo) & Mild & Yes (lepto) & Yes \\
\hline 12 & $\downarrow /=$ & Yes & yes (hetero) & Mild & No & No \\
\hline 13 & $=/ \uparrow$ & No & no & Mild & No & No \\
\hline 14 & $\downarrow / \downarrow$ & No & yes (homo) & Mild & Yes (lepto) & Yes \\
\hline 15 & $=/ \downarrow$ & No & yes (homo) & Moderate & No & No \\
\hline
\end{tabular}

$=$ isointense signal; $\downarrow$ hypointense signal; $\uparrow$ hyperintense signal; ${ }^{\circledR}$ heterogeneous; ${ }^{B h}$ homogeneous; ‘leptomeningeal.

Table 3. Pathological information.

\begin{tabular}{cccc} 
Case & Primary site of lymphoma & Biopsy site & Histopathological diagnosis \\
\hline 1 & CNS & CNS & Diffuse large B-cell NHL \\
2 & BM & BM & B-cell NHL. Bone marrow fibrosis. \\
3 & RES & Cervical lymph node & Hodgkin's disease, nodular sclerosis type Il \\
4 & BM / CNS & BM & Dow-grade NHL (lymphoplasmacytic) \\
5 & Maxillary sinus & Daxillary sinus & Large B-cell NHL \\
6 & Bronchus & Bronchus & Classical CNS HL \\
7 & CNS & CNS & B-cell NHL \\
8 & CNS & CNS & Diffuse large B-cell NHL (centroblastic) \\
9 & CNS & CNS & Diffuse large B-cell NHL (centroblastic) \\
10 & CNS & CNS & High-grade B-cell NHL \\
11 & BM / CNS & BM & Mixed cell HL \\
12 & RES & Inguinal lymph node & Diffuse large B-cell NHL \\
13 & Testis / CNS & Testis & Diffuse large B-cell NHL \\
14 & CNS & CNS & Diffuse large B-cell NHL \\
\hline
\end{tabular}

CNS: central nervous system; NHL: non-Hodgkin's lymphoma; BM: bone marrow; NA: not available; RES: reticuloendothelial system; HL: Hodgkin's lymphoma. 
Some studies report that homogeneous enhancement by contrast is a frequent finding and the absence of contrast enhancement, as we observed in one patient, as rare in intracranial lymphoma ${ }^{4,7-11}$. The perilesional white matter signal change is common in CNS lymphoma ranging from $77 \%$ to more than $90 \%$ in other series ${ }^{2,45,7,8}$, and in our paper it was found in all patients, but in varying degrees.

We found a higher proportion of patients with meningeal involvement at presentation than other authors ${ }^{2.5}$. Also, it is noteworthy that in two cases of single dural lesion, the tumor radiologically mimicked a meningioma.

In non-Hodgkin's lymphoma (NHL), secondary spread involves the CNS, usually in the form of leptomeningeal infiltrates. Parenchymal lesions, when present, typically result from secondary involvement from the leptomeninges via infiltration of the perivascular spaces ${ }^{1}$. We emphasize the finding of three cases of intracranial Hodgkin's lymphoma (Fig 3), since most cases of secondary CNS involvement by Hodgkin's lymphoma are late manifestations of disseminated disease and primary CNS involvement by this type of lymphoma is very $\operatorname{rare}^{1,13,14}$.

In conclusion, lymphoma presentations are very pleomorphic in the CNS, but some of them (single or associated) should point to this diagnostic possibility. The differential diagnosis of CNS lymphoma includes gliomas, metastasis, and inflammatory disorders. In our group of patients, the signal intensity on $\mathrm{T} 1$ and $\mathrm{T} 2$ weighted images was predominantly hypo- or isointense. In the T2 weighted images, single lesions

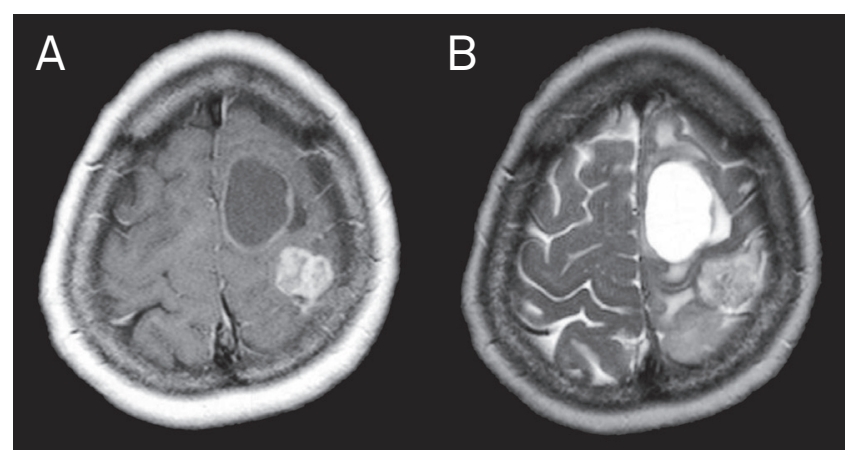

Fig 3. Case 7: Axial T1-weighted image after contrast (A) showing intra-axial lesion in the left superior frontal gyrus, with peripheral contrast enhancement. In the T2-weighted image (B), the lesion is predominantly hyperintense. The images also show an extra-axial solid lesion in the left parietal convexity, with intense contrast enhancement and isointense in the T2-weighted image. The pathology revealed primary CNS classical Hodgkin lymphoma.

were associated with a hypointense signal component. Later, we found an association of subependymal spread and meningeal involvement, findings that tended to occur in younger patients. Our analysis also showed the correlation of the hyperintense signal in the $\mathrm{T} 1$ weighted image with more pronounced perilesional changes. These radiological features, along with other findings such as location of the lesion, contrast enhancement (in the lesion and in subependymal and meningeal sites, which may be a potential clue to lymphomatous dissemination), can help this differentiation.

\section{References}

1. Slone HW, Blake JJ, Shah R, Guttikonda S, Bourekas EC. CT and MRI findings of intracranial lymphoma. AJR 2005;184:1679-1685.

2. Besada C, Schvartzman P, Paganini L, Santa Cruz D, Fues J. Neuroimágenes estructurales y funcionales en la caracterización del linfoma Del SNC. Rev Argent Radiol 2010;74:147-153.

3. Sierra del Rio M, Rousseau A, Soussain C, Ricard D, Hoang-Xuan K. Primary CNS lymphoma in immunocompetent patients. The Oncologist 2009;14:526-539.

4. Küker W, Nägele T, Korfel A, et al. Primary central nervous system lymphomas (PCNSL): MRI features at presentation in 100 patients. J Neurooncol 2005;72:169-177.

5. Koul R, Dufan T, Dubey A, et al. Imaging features of primary central nervous system lymphoma at presentation. Case series from a regional cancer centre. Oncol Exchange 2008;7:24-27.

6. Johnson BA, Fram EK, Johnson PC, Jacobowitz R. The variable MR appearance of primary lymphoma of the central nervous system: comparison with histopathologic features. AJNR Am J Neuroradiol 1997;18:563-572.

7. Bühring $U$, Herrlinger $U$, Krings $T$, Thiex R, Weller $M$, Küker $W$. MRI features of primary central nervous system lymphomas at presentation. Neurology 2001;57:393-396.

8. Haldorsen IS, Kråkenes J, Krossnes BK, Mella O, Espeland A. CT and MR imaging features of primary central nervous system lymphoma in Norway, 1989-2003. AJNR Am J Neuroradiol 2009;30:744-751.

9. Zali A, Shahzadi S, Mohammad-Mohammadi A, Taherzadeh K, Parsa K. Cerebral lymphoma: clinical and radiological findings in 90 cases. Arch Iranian Med 2007;10:194-198.

10. Zhang D, Hu LB, Henning TD, et al. MRI findings of primary CNS lymphoma in 26 immunocompetent patients. Korean J Radiol 2010;11:269-277.

11. Koeller KK, Smirniotopoulos JG, Jones RV. Primary central nervous system lymphoma: radiologic-pathologic correlation. Radiographics 1997:17:1497-1526

12. Erdag N, Bhorade RM, Alberico RA, Yousuf N, Patel MR. Primary lymphoma of the central nervous system: typical and atypical CT and MR imaging appearances. AJR 2001;1176:1319-1326.

13. Gerstner ER, Abrey LE, Schiff D, et al. CNS Hodgkin lymphoma. Blood 2008;112:1658-1661.

14. Re D, Fuchs M, Schober T, Engert A, Diehl V. CNS involvement in Hodgkin's lymphoma. J Clin Oncol 2007;25:3181. 